\title{
Effect of Synthetic Thyrotropin-Releasing Factor (TRF) on Pituitary TSH Secretion in Man
}

\author{
MASAHIRo SAKODA*, MaKoto OTSUKI*, NAOHISA HIROSHIGE, \\ KeIsUKe KANAO AKIKo YAGI AND Minoru HONDA
The Second Department of Internal Medicine, Kobe University, Medical
School, Kobe*, and Sumitomo Hospital, Osaka

\section{Synopsis}

\begin{abstract}
Synthetic thyrotropin-releasing factor (TRF), L-pyroglutamyl-L-histidil-L-prolineamide, has been administered intravenously to 35 cases of normal or suspected pituitary insufficient volunteers in doses ranging from 25 to $200 \mu \mathrm{g}$. Changes of plasma TSH levels, PBI and $T_{3}$ resin sponge uptake $\left(\mathrm{T}_{3} \mathrm{RSU}\right)$ were estimated. TRF in doses of 25-200 $\mu \mathrm{g}$ stimulates a rapid rise in plasma TSH in all of the 13 normal subjects. 3 out of 5 normal subjects showed rise in serum PBI while $\mathrm{T}_{3}$ RSU remained unchanged. The only side effect was transient nausea in several cases. No or slight rise in plasma TSH levels occurred following $100 \mu \mathrm{g}$ of TRF in patients with pituitary chromophobe adenoma and craniopharyngioma who had a longstanding pituitary insufficiency and low level of thyroid function. However, certain cases of both tumor showed almost normal TSH response to TRF. It was also noticed that no TSH response to TRF was observed in two hyperthyroid patients and one medicated with thyroid powder. Normal TSH increase following TRF was obtained from cases with suspected hypotituitarism, diabetes insipidus, arachnoiditis of chiasma region, myotonic dystrophy and a 77 years-old female. Suboptimal response were observed in a patient with suspected Cushing' syndrome. It is concluded that synthetic TRF is useful for testing the pituitary TSH reserve in man. Plasma TSH response to TRF in various clinical conditions was discussed.
\end{abstract}

The beautiful studies concerning thyrotropin-releasing factor (TRF) has revealed chemical properties and biological action of TRF in mice and rats. (Folkers et al., 1969 Bowers et al., 1970 Burgus et al., 1970 Sakoda et al., 1970) The chemical structure of TRF has been shown to be tripeptide: pyroglutamyl-histidil-proline-amide and active in releasing of pituitary thyrotropin in vivo and in vitro. However, the observation of TRF effect in man is difficult to make except the report from Bowers et al. (1968) on 3 cases with cretin, Hall et al. (1970) on 10 cases of normal subjects and Fleischer et al. (1970) on 18 cases of normal or pituitary failure. Though such a preparation of synthetic TRF is now

Received for publication December 28, 1970. available for clinical use and thought to be useful for diagnosis and treatment of hypothalamo-pituitary disorder, there could not be found any extensive observation on cases with pituitary failure who are well documented by histological diagnosis and analysed by various static or dynamic endocrinological examinations. In this paper the effect of synthetic TRF on 13 cases with normal subjects and on 22 cases of documented or suspected pituitary failure will be presented.

\section{Materials and Methods}

\section{Thyrotropin-Releasing Factor (TRF)}

Thyrotropin-releasing factor used in this study was synthesized by the joint work of Dr. Sakoda and the 
Daigo Nutritive Chemicals, Ltd.* following the method of Gillessen et al. (1970) with slight modification. It was presented as pyroglutamyl-histidil-prolineamide in the form of the acetate salt. TRF activity of this preparation was determined with in vivo and in vitro methods. Acute toxicity was tested in mice and subacute toxicity was examined by for intraperitoneal injections 30 days of synthetic TRF in to rats before initiating this study. Synthetic TRF was administered intravenously for over $30 \mathrm{sec}$ in doses of 25 to $200 \mu \mathrm{g}$. Blood samples were obtained from cubital vein and plasma was stored at $-20^{\circ} \mathrm{C}$ until assay.

\section{Determination of HTSH in the plasma}

Plasma HTSH concentrations were measured by means of radio-immunoassay using the double antibody technique. Purified HTSH preparation for labeling with radioactive iodine and antiserum to HTSH were supplied by the National Institute of Health Endocrinology Study Section. The Human Thyrotropin Research Standard A was used as standard. HTSH was labelled with ${ }^{125} \mathrm{I}$ by the method of Greenwood et al. (1963). Assay was performed by a modification of the method which was described in the brochure accompanying the preparations. Using $1 \%$ bovine serum albumin in the buffer of first incubation instead of $2 \%$ normal rabbit serum, and adding $1 \%$ normal rabbit serum at the starting time of second reaction, we could decrease the consumption of second antibody. Standards were diluted in buffer containing plasma from pituitarigenic hypothyroid subject; thus all tubes in the assay contained the same volume of plasma. Figure 1 shows the system of assay employed. The ratio of the antibody bound ${ }^{125}$ I-HTSH (B) to total $(\mathrm{T})$ was then calculated. Standard curves were drawn by plotting the $\mathrm{B} / \mathrm{T}$ ratio against varying amounts of standard. Minimal-detectable level was $1.7 \mu \mathrm{U} / \mathrm{m} l$. in our laboratory.

\section{Estimation of Thyroid hormone levels}

The serum protein-bound iodide (PBI) was measured by the autoanalyzer technique. Mean level of $\mathrm{PBI}$ in 30 normal subjects was $5.0 \mu \mathrm{g} / \mathrm{d} l \pm 0.84$ (standard Error) in our laboratory. An indirect estimation of serum thyroid hormone concentration was performed with $T_{3}$ resin sponge uptake $\left(T_{3}-R S U\right.$ : Dinabot R.I. Lab., Ltd.)

\section{Estimation of plasma $\mathrm{HGH}$ and urinary corti- costeroid}

Plasma HGH were measured by radioimmunoas-

\footnotetext{
* This preparation was released by Daigo Nutritive Chemicals, Ltd. The company is in no way implicated in the administration to volunteers.
}

1. Buffer $(0.01 M$ phosphate, $0.15 M \mathrm{NaCl}, 1 \%$ bovine serum albumin, $0.1 \%$ sodium azide, $\mathrm{pH}$ 7.8) to make total volume $0.9 \mathrm{~m} l$.

2. $0.1 M$ EDTA, $0.1 \mathrm{~m} l$.

3. 10 international units of human chorinoic gonadotropin.

4. Plasma to be assayed, $0.3 \mathrm{~m} l$ or less, or standard.

5. Anti-H TSH rabbit serum at a dilution of 1 : 20,000, $0.1 \mathrm{ml}$.

$\downarrow \quad$ incubate at $4^{\circ} \mathrm{C}$ for $24 \mathrm{hr}$.

${ }^{125} \mathrm{I}$-HTSH $(0.1 \mathrm{~m} \mu \mathrm{g}$ or less) disolved in above buffer, $0.1 \mathrm{~m} l$.

$\downarrow \quad$ incubate at $4^{\circ} \mathrm{C} 4-5$ days.

1. Goat antiserum to rabbit $\gamma$-Globulin at a dilution $1: 10,0.1 \mathrm{ml}$.

2. $1 \%$ normal rabbit serum, $0.1 \mathrm{ml}$.

$\downarrow \quad$ incubate at $4{ }^{\circ} \mathrm{C}$ for $24 \mathrm{hr}$.

Count (total counts)

Centrifuge at $3,000 \mathrm{rpm}$ for $30 \mathrm{~min}$

precipitate

supernatant

$\downarrow$

Count (ppt counts)

Fig. 1. Assay system of plasma HTSH.

say using the double antibody technique after Schalch and Parker (1964). Urinary total 17 OHCS were estimated after Reddy et al. (1952) with slight modification and total $17 \mathrm{KS}$ by modified method of Zimmermann (Miyake, 1955). $3.0 \mathrm{~g}$ of SU 4885 was administered orally on the second day of examination.

\section{Clinical subjects}

Synthetic TRF was administered to 35 volunteers. The first 13 including one of the authors were healthy male volunteers who had no clinical or laboratorical evidence of thyroid disease. Subsequent volunteers were informed of the purpose of this study and of the experience of those who had received synthetic TRF. Verbal permission to perform these studies was obtained from the volunteers or their family by Dr. Sakoda or Dr. Otsuki. In addition to healthy subjects, TRF was given to 7 patients with pituitary chromophobe adenoma, 3 with craniopharyngioma, 5 with suspected pituitary failure, 2 with hyperthyroidism, 1 with diabetes insipidus, thyroid powder medica- 
Table 1. Effect of synthetic TRF on plasma TSH levels in normal subjects.

\begin{tabular}{|c|c|c|c|c|c|c|c|c|c|c|c|c|}
\hline \multirow[b]{2}{*}{ Case No. } & \multirow[b]{2}{*}{ Age } & \multirow[b]{2}{*}{ Sex } & \multirow{2}{*}{$\begin{array}{c}\text { Doses } \\
(\mu \mathrm{g})\end{array}$} & \multicolumn{9}{|c|}{ Plasma TSH $(\mu \mathrm{U} / \mathrm{m} l)}$. \\
\hline & & & & 0 & 5 & 10 & 15 & 20 & 30 & 60 & 90 & $\begin{array}{l}120 \\
\min \end{array}$ \\
\hline 1 & 20 & $\mathrm{~F}$ & 25 & - & 12.6 & 6.6 & 3.3 & 2.6 & 2.0 & 2.6 & - & - \\
\hline 2 & 22 & $\mathrm{~F}$ & 25 & - & 3.0 & 4.0 & 5.9 & 5.9 & 7.3 & 2.6 & - & - \\
\hline 3 & 30 & M & 25 & - & - & 6.6 & - & - & - & - & - & - \\
\hline 4 & 26 & $\mathbf{M}$ & 50 & 2.6 & 4.8 & 8.6 & 7.3 & 6.9 & 6.9 & 4.0 & 4.3 & 4.0 \\
\hline 5 & 27 & $\mathrm{M}$ & 50 & - & 4.0 & 8.6 & 8.6 & 12.5 & 9.9 & 6.6 & 4.0 & 3.3 \\
\hline 6 & 29 & M & 50 & - & 3.3 & 4.3 & 4.6 & 6.6 & 5.3 & 3.3 & 3.3 & 4.0 \\
\hline 7 & 37 & $\mathbf{M}$ & 50 & - & 2.6 & 4.6 & 5.9 & 4.8 & 4.6 & 4.0 & 2.6 & 1.7 \\
\hline 8 & 26 & $\mathbf{M}$ & 100 & 1.7 & 4.8 & 3.6 & 5.4 & 10.5 & 9.0 & 6.0 & 1.7 & 1.7 \\
\hline 9 & 27 & $\mathbf{M}$ & 100 & 2.6 & 5.6 & 9.2 & 9.2 & 9.2 & 8.3 & 5.6 & 2.6 & 3.0 \\
\hline 10 & 27 & $\mathbf{M}$ & 100 & 1.7 & 4.3 & 3.6 & 6.6 & 5.9 & 4.6 & 4.0 & 1.7 & 2.3 \\
\hline 11 & 28 & M & 100 & - & 2.3 & 8.3 & 10.0 & 7.6 & 6.6 & 2.6 & 1.7 & 1.7 \\
\hline 12 & 27 & $\mathrm{M}$ & 200 & - & 2.6 & 11.9 & 11.9 & 8.6 & 7.4 & 6.6 & 1.7 & 1.7 \\
\hline 13 & 38 & $\mathbf{M}$ & 200 & - & 6.9 & 13.2 & 23.1 & 22.1 & 23.2 & 13.2 & 7.6 & 7.9 \\
\hline
\end{tabular}

- represents TSH value below $1.7 \mu \mathrm{U} / \mathrm{m} l$.

tion, myotonic dystrophy, arachnoiditis, suspected Cushing' syndrome and 77-years-old female. All pituitary chromophobe adenoma and craniopharyngioma were determined by means of histological examination after craniotomy.

\section{Results}

\section{Effect of TRF on normal subjects}

Intravenous administration of synthetic TRF in doses of 25-200 $\mu \mathrm{g}$ stimulates a rise in plasma TSH levels in all normal subjects. (Fig. 2, Table 1) A detectable rise was observed within $5 \mathrm{~min}$ and further rise followed over next $20 \mathrm{~min}$. Peak level occurred at 15-20 min after TRF injection with gradual fall over the next $120 \mathrm{~min}$. $25 \mu \mathrm{g}$ or more of synthetic TRF was effective in all cases examined in this study. Maximum value of TSH increase in this study is $23.1 \mu \mathrm{U} / \mathrm{ml}$ (1359.0\% of initial) in a case given $200 \mu \mathrm{g}$ of TRF. The cases given higher doses of TRF showed the longer duration of increased TSH levels. The effect of TRF on serum PBI levels is shown in Table 2. Serum PBI increase was observed in 3 out of 5 subjects $90-120$ minutes after TRF but PBI response was not
Table 2. Effect of TRF on serum PBI levels in normal subjects

\begin{tabular}{|c|c|c|c|c|c|c|c|c|}
\hline \multirow{2}{*}{$\begin{array}{l}\text { Case } \\
\text { No. }\end{array}$} & \multirow[b]{2}{*}{ Age } & \multirow[b]{2}{*}{ Sex } & \multirow{2}{*}{$\begin{array}{c}\text { Doses } \\
(\mu \mathrm{g})\end{array}$} & \multicolumn{5}{|c|}{ Serum PBI $(\mu \mathrm{g} / \mathrm{d} l)}$. \\
\hline & & & & 0 & 30 & 60 & 90 & $\begin{array}{c}120 \\
\text { min }\end{array}$ \\
\hline 1 & 28 & M & 50 & 3.4 & 3.4 & 3.4 & 4.4 & 4.8 \\
\hline 2 & 27 & M & 50 & 4.8 & 4.6 & 5.2 & 7.2 & 5.4 \\
\hline 3 & 29 & M & 50 & 4.2 & 3.6 & 3.6 & 3.8 & 3.4 \\
\hline 4 & 37 & M & 50 & 5.0 & 5.2 & 5.4 & 5.1 & 5.3 \\
\hline 5 & 38 & M & 200 & 3.0 & 3.8 & 3.6 & 4.0 & 3.8 \\
\hline
\end{tabular}

so consistent. There was no change in $T_{3}$ RSU.

\section{Effect of TRF on pituitary chromophobe denoma and craniopharyngioma}

Since peak TSH levels were observed 1520 min after $100 \mu \mathrm{g}$ of TRF was injected and maximum TSH value was over $5.9 \mu \mathrm{U} / \mathrm{m} l$ in all normal subjects as described previously, patients who showed under $5.0 \mu \mathrm{U} / \mathrm{m} l$ of maximum TSH value at $20 \mathrm{~min}$ were postulated as cases of "suboptimal response." Although further observations in normal and pituitary insufficient subjects seems to be necessary to ascertain these criteria. Follow- 


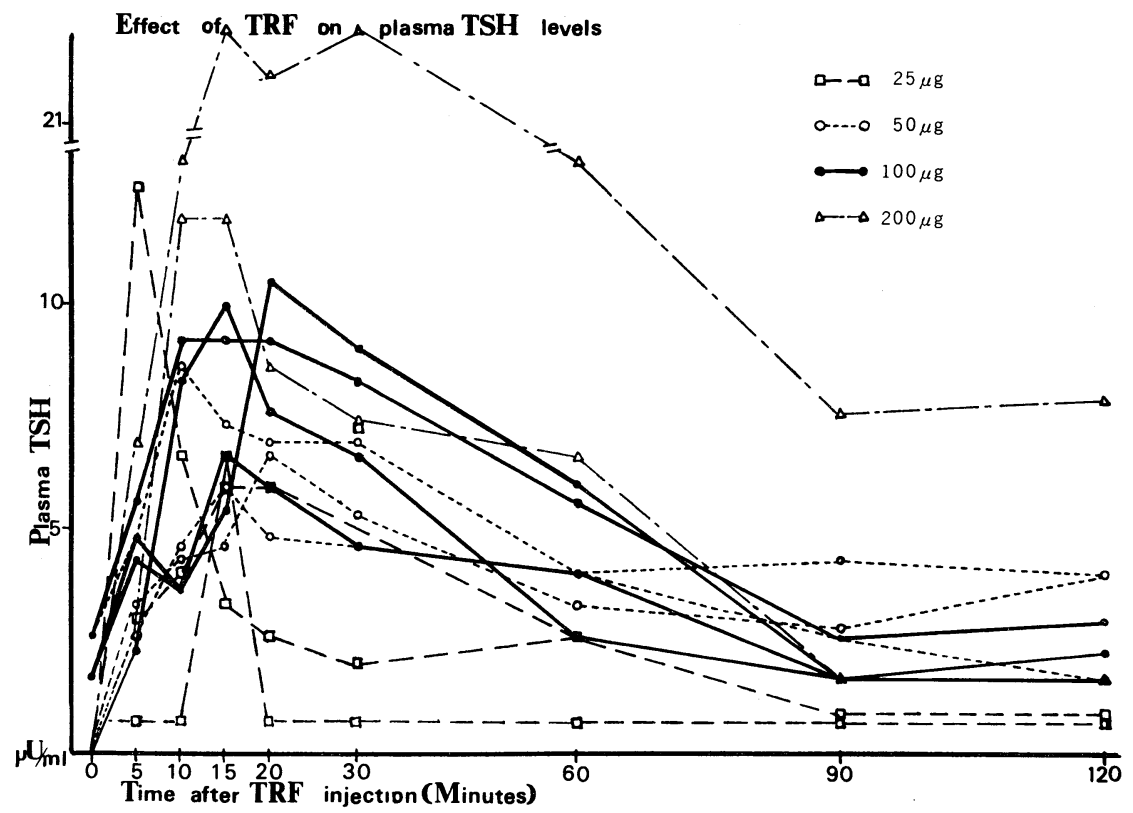

Fig. 2. Effect of 25-200 $\mu \mathrm{g}$ TRF on plasma TSH levels in normal subjects.

Table 3. Effect of Synthetic TRF on plasma TSH levels

(I) Pituitary Chromophobe Adenoma

\begin{tabular}{|c|c|c|c|c|c|c|c|c|c|c|c|}
\hline \multicolumn{2}{|c|}{ Patient } & \multirow{2}{*}{$\begin{array}{l}\text { Duration } \\
\text { from onset }\end{array}$} & \multirow{2}{*}{$\begin{array}{l}{ }^{60} \text { Cobalt } \\
\text { radiation }\end{array}$} & \multicolumn{5}{|c|}{$\mathrm{TSH}(\mu \mathrm{U} / \mathrm{m} l)$ response to $\underset{\text { TRF }}{\mathrm{T}}$} & \multirow{2}{*}{$\begin{array}{c}\text { BMR } \\
(\%)\end{array}$} & \multirow{2}{*}{$\begin{array}{c}\text { PBI } \\
(\mu \mathrm{g} / \mathrm{d} l)\end{array}$} & \multirow{2}{*}{$\underset{(\%)}{\mathrm{T}_{3} \mathrm{RSU}}$} \\
\hline Name & $\begin{array}{l}\text { (yrs.) } \\
\& \text { sex }\end{array}$ & & & 0. & 10. & 20. & 30. & 60. & & & \\
\hline T.O. & 49.F. & 12 years & & 3.0 & 2.4 & 3.0 & 2.4 & 3.0 & -20 & 2.0 & 24.5 \\
\hline S.K. & 46.F. & 4 years & $5000 \mathrm{R}$ & —* & - & 3.6 & - & - & +12 & 3.4 & 22.9 \\
\hline S.M. & 43.F. & 1 year & 3000R & 1.8 & 6.6 & 14.2 & 13.2 & 13.2 & -32 & 5.0 & 30.0 \\
\hline Y.N. & 26.F. & 4 years & $5000 \mathrm{R}$ & - & 5.0 & 7.9 & & 8.0 & -24 & 4.0 & \\
\hline H.T. & 21.F. & 3 years & $5200 \mathrm{R}$ & - & 6.9 & 13.9 & 18.5 & 10.6 & -10 & 5.4 & 32.1 \\
\hline M.M. & 58.M. & 8 years & $5000 \mathrm{R}$ & - & - & 4.0 & - & 4.0 & -9 & 4.2 & 28.8 \\
\hline T.S. & 43.M. & 2 years & $5000 \mathrm{R}$ & - & - & - & - & - & -50 & 2.8 & 28.1 \\
\hline
\end{tabular}

(II) Craniopharyngioma

\begin{tabular}{|c|c|c|c|c|c|c|c|c|c|c|c|}
\hline & & Duration & & & $\mathrm{I}(\mu \mathrm{U}$ & l) res & nse to & & & & \\
\hline Name & $\begin{array}{l}\text { (yrse) } \\
\text { \& sex }\end{array}$ & $\begin{array}{l}\text { from } \\
\text { onset }\end{array}$ & radiation & 0 . & 10. & 20. & 30. & 60. & $\frac{\mathrm{BMR}}{(\%)}$ & $(\mu \mathrm{g} / \mathrm{d} l)$ & $\begin{array}{c}\mathrm{T}_{3} \mathrm{RSU} \\
(\%)\end{array}$ \\
\hline K.T. & 25.M. & 14 years & $5000 \mathrm{R}$ & 一 & - & 2.2 & - & - & -31 & 3.8 & 21.6 \\
\hline K.Y. & 6.M. & 2 years & & 3.6 & - & 8.7 & 13.5 & 8.4 & -36 & 3.8 & 24.0 \\
\hline Y.M. & 39.F. & 11 months & & - & 14.2 & 16.5 & 19.2 & 9.3 & -8 & - & 28.1 \\
\hline
\end{tabular}

\footnotetext{
*_ represents TSH value below $1.7 \mu \mathrm{U} / \mathrm{m} l$.
} 
ing these criteria TRF effect was analysed in patients with pituitary adenoma and craniopharyngioma. 4 out of 7 cases with pituitary chromophobe adenoma showed suboptimal TSH response after $100 \mu \mathrm{g}$ of TRF injection while the other 3 cases responded normally. In 3 cases with cranio pharyngioma 1 case responded suboptimally and the other 2 cases showed normal TSH response. (Fig. 3, Table 3) Response of plasma TSH levels to TRF appeared to be dependent on the functional capacity of the pituitary gland to secrete TSH.

Effect of TRF on suspected pituitary failure

In each case with suspected craniopharyngioma (sella enlargement and calcification in the suprasellar region), pituitary neoplasma (sella enlargement) and diabetes insipidus, TRF elevated plasma TSH levels as in normal subjects. In suspected craniopharyngioma and diabetes insipidus TRF stimulated a rise in plasma TSH level but the peak rise was not so great as that observed in normal individuals. Two cases with suspected pituitary insufficiency showed normal TSH response to TRF. (Table 4, Fig. 4)

Effect of TRF on the other endocrine disorder

In two patients with hyperthyroidism TRF administration had no detectable effect on plasma TSH levels. No TSH rise was also observed in patients receiving $60 \mu \mathrm{g}$ of thyroid powder per day. Myotonic dystrophy, arachnoiditis in the chiasma region, a 77-years-old female responded quite normally to TRF. One case with suspected Cushing' syndrome showed suboptimal response. (Table 4)

\section{Side effect of synthetic TRF}

Transient nausea was noted in several cases arising just after injection. There was no

in various Endocrine Disorder-(I)

\begin{tabular}{|c|c|c|c|c|c|c|c|c|c|c|c|}
\hline \multirow{2}{*}{$\underset{(\min )}{\mathrm{HGH}}($} & \multirow{3}{*}{$\begin{array}{l}0 . \\
80 \\
11.8\end{array}$} & \multirow{3}{*}{$\begin{array}{l}20 . \\
46 \\
21.4\end{array}$} & \multirow{3}{*}{$\begin{array}{l}40 . \\
26 \\
15.2\end{array}$} & \multirow{3}{*}{$\begin{array}{l}60 . \\
40 \\
12.0\end{array}$} & \multirow{3}{*}{$\begin{array}{l}90 . \\
54 \\
13.6\end{array}$} & \multirow{3}{*}{$\begin{array}{l}120 . \\
60 \\
10.4\end{array}$} & \multirow{2}{*}{\multicolumn{2}{|c|}{$\begin{array}{c}\text { Urinary } \\
\text { corticosteroid } \\
\text { 170HCS 17KS } \\
(\mathrm{mg} / 24 \mathrm{hr})\end{array}$}} & \multicolumn{3}{|c|}{$\begin{array}{c}\text { SU4885 test Urinary } \\
170 \mathrm{HCS}(\mathrm{mg} / 24 \mathrm{hr})\end{array}$} \\
\hline & & & & & & & & & Day1 & Day2 & Day3 \\
\hline $\begin{array}{l}\text { B.G.**: } \\
\text { HGH }\end{array}$ & & & & & & & 0.1 & 0.3 & 0.1 & 2.0 & 2.2 \\
\hline & & & & & & & $\begin{array}{r}10.5 \\
4.8\end{array}$ & $\begin{array}{l}6.0 \\
2.8\end{array}$ & 4.8 & 6.8 & 3.8 \\
\hline $\begin{array}{l}\text { B.G. } \\
\text { HGH }\end{array}$ & $\begin{array}{l}70 \\
6.6\end{array}$ & $\begin{array}{l}30 \\
14.4\end{array}$ & $\begin{array}{l}46 \\
8.6\end{array}$ & $\begin{array}{l}74 \\
10.6\end{array}$ & $\begin{array}{c}68 \\
9.6\end{array}$ & $\begin{array}{l}60 \\
8.8\end{array}$ & 2.7 & $\begin{array}{l}6.2 \\
3.8\end{array}$ & 2.7 & 5.1 & 8.4 \\
\hline $\begin{array}{l}\text { B.G. } \\
\text { HGH }\end{array}$ & $\begin{array}{l}82 \\
2.1\end{array}$ & $\begin{array}{l}40 \\
1.1\end{array}$ & $\begin{array}{l}40 \\
1.7\end{array}$ & $\begin{array}{c}64 \\
1.4\end{array}$ & $\begin{array}{c}46 \\
9.3\end{array}$ & $\begin{array}{l}60 \\
2.4\end{array}$ & 4.8 & 2.4 & & & \\
\hline
\end{tabular}

\begin{tabular}{|c|c|c|c|c|c|c|c|c|c|}
\hline \multicolumn{10}{|c|}{ 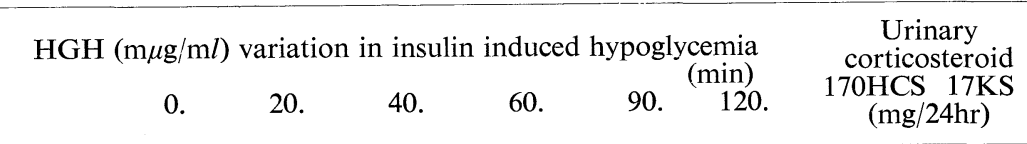 } \\
\hline $\begin{array}{l}\text { B.G. } \\
\text { HGH }\end{array}$ & : & $\begin{array}{l}62 \\
12.4\end{array}$ & $\begin{array}{l}20 \\
8.8\end{array}$ & $\begin{array}{l}32 \\
5.6\end{array}$ & $\begin{array}{c}34 \\
5.4\end{array}$ & $\begin{array}{l}48 \\
1.4\end{array}$ & $\begin{array}{l}56 \\
9.8\end{array}$ & 6.7 & 1.0 \\
\hline $\begin{array}{l}\text { B.G. } \\
\text { HGH }\end{array}$ & $:$ & $\begin{array}{l}72 \\
12.8\end{array}$ & 28 & $\begin{array}{l}48 \\
5.8\end{array}$ & $\begin{array}{l}52 \\
2.4\end{array}$ & $\begin{array}{l}58 \\
12.4\end{array}$ & $\begin{array}{c}68 \\
9.6\end{array}$ & 2.2 & 0.9 \\
\hline $\begin{array}{l}\text { B.G. } \\
\text { HGH }\end{array}$ & : & $\begin{array}{l}108 \\
10.0\end{array}$ & $\begin{array}{l}67 \\
0.8\end{array}$ & $\begin{array}{c}56 \\
1.6\end{array}$ & $\begin{array}{l}75 \\
1.4\end{array}$ & $\begin{array}{c}87 \\
0.9\end{array}$ & $\begin{array}{l}86 \\
12.2\end{array}$ & & \\
\hline
\end{tabular}

**B.G. means blood glucose $(\mathrm{mg} / \mathrm{d} l)$ 

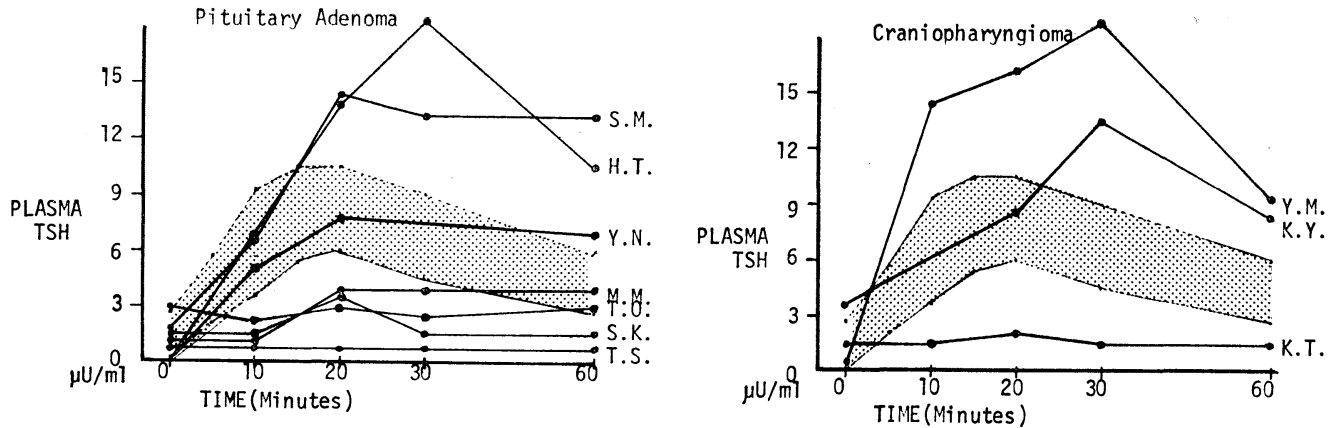

Fig. 3. Effect of $100 \mu \mathrm{g}$ TRF on plasma TSH levels in patients with pituitary adenoma and cra-niopharyngioma. The shaded area indicates the range of response seen in normal subjects receiving $100 \mu \mathrm{g}$ TRF.

Table 4. Effect of Synthetic TRF on plasma TSH levels in various

(I) Suspected Pituitary Failure

\begin{tabular}{|c|c|c|c|c|c|c|c|c|c|c|c|}
\hline Pati & Age & & $\mathrm{H}(\mu \mathrm{U}$ & ) resp & se to 7 & & BMR & PBI & $\mathrm{T}_{3} \mathrm{RSU}$ & $\begin{array}{l}\text { Urinary c } \\
(\mathrm{mg}\end{array}$ & $\begin{array}{l}\text { rticosteroid } \\
\text { /24hr) }\end{array}$ \\
\hline Name & $\begin{array}{l}\text { (yrs.) } \\
\& \text { sex }\end{array}$ & 0. & & 20. & 30. & n) & $(\%)$ & $(\mu \mathrm{g} / \mathrm{d} l)$ & $(\%)$ & $170 \mathrm{HCS}$ & $17 \mathrm{KS}$ \\
\hline I.S. & 43.M. & 一* & 4.8 & 5.4 & 1.8 & 2.4 & -5 & 5.4 & 32.0 & 1.3 & 1.7 \\
\hline Y.Y. & 50.M. & 3.3 & 9.9 & 15.0 & 1216 & 9.9 & -10 & 7.6 & 25.0 & 2.4 & 0.1 \\
\hline H.C. & 42.F. & 1.8 & 2.4 & 6.3 & 7.5 & 2.1 & +3 & 4.2 & 28.5 & & \\
\hline N.M. & 17.M. & 2.4 & 7.5 & & 5.1 & & -40 & 3.0 & 24.0 & & \\
\hline T.H. & 40.F. & 2.6 & 6.6 & 12.2 & 16.5 & 10.5 & -8 & 3.8 & 22.4 & 3.5 & 0.1 \\
\hline (II) & Hypertl & yroidi & & & & & & & & & \\
\hline M.S. & 26.M. & - & - & - & - & - & +57 & 10.0 & 46.4 & & \\
\hline K.M. & 34.F. & - & - & - & - & - & +32 & 5.6 & 48.4 & & \\
\hline (III) & Thyroi & Horr & ne Adr & istrati & & & & & & & \\
\hline H.Y. & 26.M. & - & - & - & - & - & -30 & 5.0 & & 0.1 & 1.1 \\
\hline (IV) & Others & & & & & & & & & & \\
\hline M.K. & 33.M. & 1.7 & 9.6 & 9.0 & 9.6 & 9.6 & -10 & & 24.7 & & \\
\hline K.U. & 32.M. & 2.1 & 2.1 & 7.8 & 7.8 & 7.5 & -28 & 5.2 & 24.7 & 4.6 & 3.9 \\
\hline H.S. & 77.F. & 3.3 & 9.0 & 10.5 & 16.0 & 11.4 & & & & & \\
\hline M.T. & 41.F. & 一 & 2.6 & 3.3 & 2.6 & 1.7 & -24 & 3.8 & 32.5 & 31.4 & 11.3 \\
\hline
\end{tabular}

*_ represents TSH value below $1.7 \mu \mathrm{U} / \mathrm{m} l$. 


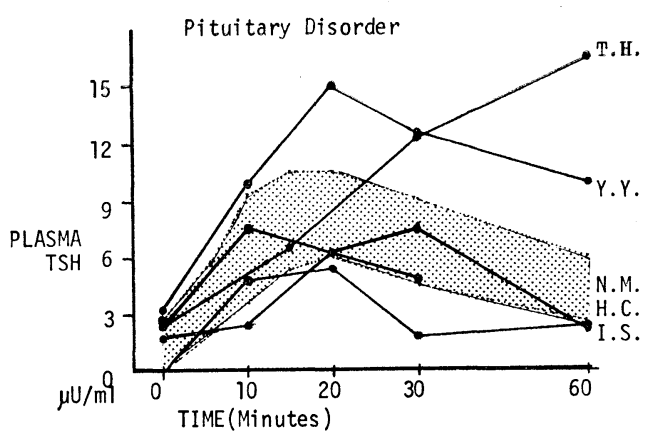

Fig. 4. Effect of $100 \mu \mathrm{g}$ TRF on plasma TSH levels in patients with suspected pituitary failure. The shaded area indicates the range of response seen in normal subjects receiving $100 \mu \mathrm{g}$ TRF.

more side effect except nausea. Liver function and blood analysis showed no change before and after TRF injection.

Endocrine Disorder-(2)

\section{Clinical Findings}

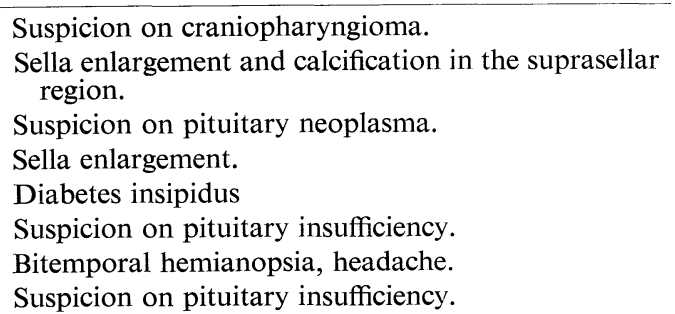

Palpitation, tremor, thyroid enlargement and excessive sweating.

Tachycardia, tremor, thyroid enlargement, eye signs and excessive sweating.

Pituitary insufficiency. Suspicion on pinealoma.

Thyroid powder is administered $60 \mathrm{mg}$ daily.

\footnotetext{
Arachnoiditis in the chiasma region.

Myotonic dystrophy.
}

Suspicion on Cushing's syndrome.

\section{Discussion}

A synthetic TRF preparation induced a significant rise in plasma TSH levels of healthy subjects. Time-course of TSH response in our study was in good agreement with the report by Bowers et al. (1968), Hall et al. (1970) and Fleischer et al. (1970). A detectable TSH rise was observed within $5 \mathrm{~min}$ and peak levels occurred 15-20 min after TRF injection. $25 \mu \mathrm{g}$ or more of synthetic TRF was effective in all healthy cases. These findings of ours are also similar to those of Hall et al. (1970). However, Bowers et al. (1968) reported that $300 \mu \mathrm{g}$ of purified porcine TRF was effective for cretins and that it would be necessary to give $20 \mu \mathrm{g}$ of pure TRF to these cretins to elicit comparable response, while Fleischer et al. (1970) administered 250 to $750 \mu \mathrm{g}$ to their normal. $\mathrm{T}_{4}$ treated and pituitary insufficient subjects. Although there is some dissecrepancy in the reported effective dose of TRF which partly depends on the purity of TRF preparation, it seems to be effective in a dose of $25 \mu \mathrm{g}$ from our present observations. Since the site of action of TRF was thought to be at pituitary level from previous experiments in vivo and in vitro by Sakoda et al. (1970), it was imagined that plasma TSH increase could not be observed in some patients with complete destruction of anterior pituitary. Indeed, certain cases of well documented pituitary chromophobe adenoma and craniopharyngioma did not show any increase. These results are in good agreement with the report by Fleischer et al. (1970) who used a synthetic TRF in three panhypopituitarisms. These nonresponsive cases of ours had almost usually low thyroid function as well as longstanding pituitary lesion, and no correlation between the age or ${ }_{60}$ Cobalt irradiation and TSH response was observed. (Table 3, Table 4).

Suboptimal response in one patient with craniopharyngioma showed either the presence of the hypothalamic lesion or the 
influence of ${ }^{60}$ Cobalt irradiation which influenced the responsibility to TRF. However, certain cases of TRF-responsive patients of pituitary adenoma or craniopharyngioma have lower thyroid function than TRF-nonresponsive cases indicating a discrepancy between the so-called static level of pituitary function and reserve capacity of pituitary response. There are some cases with pituitary failure reacting to paradoxical response who showed higher TSH levels after TRF administration than those of healthy subjects. These findings are quite difficult to explain but individual responsebility to TRF may be a moment in this phenomenon. Further observations seem to be necessary to determine an optimal dose of TRF for correct diagnosis of partial pituitary insuffeicency. Attempts to develop a loading test for TSH release have been unsuccessful and it was difficult to diagnose a partial TSH insufficiency. TRF test would become a useful one for diagnosis of a minor degree of pituitary TSH deficiency. Use of TRF is also convenient for the differential diagnosis between pituitary and hypothalamic lesions affecting pituitary TSH secretion.

It has been noticed in this study that 2 patients with hyperthyroidism showed no TSH response to TRF. Though there are several reports in which thyroid hormone inhibits TRF action in vivo and in vitro (Vale et al., 1967 Bowers et al., 1970), and as described before a case receiving thyroid powder can not evoke plasma TSH rise, it is very difficult to determine whether these non-TSH responses depend on high level of PBI or on particular pituitary responsebility in hyperthyroidism. Each case of diabetes insipidus and arachnoiditis in the chiasma region showed almost normal TSH response.

TRF inducing TSH response was also observed in a patient with myotonic dystrophy which frequently complicated multiple endocrinopathies. Quite suggestive response was obtained in 77-years-old female who responded normally to TRF indicating that the role of TSH secreting system of the pituitary is not essential for aging process. It is of interest that a case with suspected Cushing' syndrome responded suboptimally. Finally, it was concluded that there could not be proved any correlation between the TRF induced TSH response and hypoglycemia induced $\mathrm{HGH}$ response as seen in Table 3 in which cases with non-HGH response showed almost normal TSH response. However, cases with non-TSH response almost usually accompanied non-HGH response. Though further observations with expansive cases will be necessary in future, it may be said that pituitary GH secretion might be disturbed in an earlier stage of pituitary failure than that of TSH. There also could not be seen any parallelism with urinary $170 \mathrm{HCS}, 17 \mathrm{KS}$ levels or responses in SU 4885 test to TRF induced $\mathrm{TSH}$ response.

\section{Acknowledgment}

We are very grateful to Dr. Atsushi Watanabe of Daigo Nutritive Chemicals, Ltd. for synthesizing and supplying thyrotropin-releasing factor.

\section{References}

Bowers. C. Y., A. V. Schally, W. D. Hawley, Carlos Gusl, and Albert Parlow (1968). J. Clin. Endocrinol. 28, 978.

Bowers, C. Y., A. V. Schally, F. Enzmann, J. Boler, and K. Folkers (1970). Endocrinology 86, 1143.

Burgus, R., T. F. Dunn, D. M. Desidero, D. L. Ward, W. Vale, and R. Guillemin (1970). Ibid. 86, 573.

Fleischer, N., R. Burgus, W. Vale, T. Dunn, and R. Guillemin (1970). J. Clin. Endocrinol. 31, 109.

Folkers, K., F. F. Enzmann, J. Boler, C. Y. Bowers and A. V. Schally (1969). Biochem. Biophys. Res. Comm. 37, 123.

Gillessen, D., A. M. Felix, W. Largier, and R. O. Studer (1970). Helv. Chim. Acta 53, 63. 
Greenwood, F. C., W. M. Hunter, and J. S. Sakoda, M., M. Otsuki, T. Kusaka, H. Mori Glover (1963). Biochem. J. 89, 114. and T. Mineyama (1970). Kobe J. Med. Sci. Hall, M., J. Amos, R. Garry, and R. L. Buxton (1970). Brit. Med. J. 2, 274.

Miyake, T. (1955). Folia Endocrinol. Japon. 26, 122. (In Japanese) (in press)

Schalch, D. S. and M. L. Parker (1964). Nature 203, 1142.

Vale, W., R. Burgus, and R. Guillemin (1967).

Reddy, J. J., Jenkins, D. and G. W. Thorn Proc. Soc. Exp. Biol. Med. 125, 210.

(1952). Metabolism 2, 511. 